\title{
TARGETED DRUG DELIVERY SYSTEM; NANOPARTICLE BASED COMBINATION OF CHITOSAN AND ALGINATE FOR CANCER THERAPY: A REVIEW
}

\section{ADE IRMA SURYANI ${ }^{*}$, NASRUL WATHONI ${ }^{2}$, MUCHTARIDI MUCHTARIDI ${ }^{3}$, I. MADE JONI ${ }^{4,5}$}

\begin{abstract}
${ }^{1}$ Master Program in the Department of Pharmaceutics and Pharmaceutical Technology, Faculty of Pharmacy, Universitas Padjadjaran, Sumedang 45363, Indonesia, 'Department of Pharmaceutics and Pharmaceutical Technology, Faculty of Pharmacy, Universitas Padjadjaran, Sumedang 45363, Indonesia, ${ }^{3}$ Department of Pharmaceutical Analysis and Medicinal Chemistry, Faculty of Pharmacy, Universitas Padjadjaran, Sumedang 45363, Indonesia, ${ }^{4}$ Department of Physics, Faculty of Mathematics and Natural Sciences, Universitas Padjadjaran, Sumedang 45363, Indonesia, ${ }^{5}$ Functional Nano Powder University Center of Excellence (FiNder U CoE), Universitas Padjadjaran, Jalan Raya Bandung-Sumedang Km 21, Jatinangor 45363, Indonesia
\end{abstract}

"Email: ade20011@mail.unpad.ac.id

Received: 05 Aug 2021, Revised and Accepted: 15 Oct 2021

\section{ABSTRACT}

This review aimed to determine the potential of the combination of chitosan and alginate as a targeted drug carrier in cancer therapy. This article is based on the results of previous research journals collected from Google Scholar, Scopus, PubMed and Science Direct sites using the keywords chitosan, alginate, targeted drug delivery for cancer, nanoparticle chitosan alginate. With the inclusion criteria, only English-language journals, journals published in the last $10 \mathrm{y}$, related to chitosan and alginate-based formulations. Meanwhile, the exclusion criteria were journals on pharmacological properties and bioactivity, food and cosmetics. The combination of cationic chitosan and anionic alginate forming strong cross-links showed good mucoadhesive properties, higher resistance to low $\mathrm{pH}$ and high-efficiency encapsulation without showing any obvious cytotoxicity. Ch/Alg can overcome the shortcomings of the active substance, such as its rapid release process and the required active ingredient is lower than that required to enter the cancer target cells so as to minimize side effects of the drug by providing drug-induced release. in response to various stimuli that are well suited to the intended purpose, such as $\mathrm{pH}$ stimuli, redox gradients, light, temperature, and magnetism. It is shown that the combination of chitosan and alginate base has great potential in targeting cancer therapy by increasing its therapeutic effectiveness and selectivity.

Keywords: Nanoparticles, Chitosan, Alginate, Cancer therapy, Targeted delivery, Polymer

(C) 2021 The Authors. Published by Innovare Academic Sciences Pvt Ltd. This is an open access article under theCC BYlicense (https://creativecommons.org/licenses/by/4.0/) DOI: https://dx.doi.org/10.22159/ijap.2021.v13s4.43818 Journal homepage: https://innovareacademics.in/journals/index.php/ijap

\section{INTRODUCTION}

Cancer cells arise from the transformation of normal cells so that anticancer drugs can usually damage normal cells so that a drug delivery system that is specifically targeted towards cancer cells is needed such as nanoparticles [1, 2]. Nanoparticles can be defined as nano-sized systems with diameters generally ranging from 10 to 1000 $\mathrm{nm}$ [3], which has been recognized to have great potential in changing the pharmacokinetic profile, reducing side effects, and being able to increase therapeutic efficiency $[4,5]$. In the development of this delivery system, there are three main aspects, namely the targeting group, the therapeutic agent, and the carrier system. Drugs can be conjugated into carrier molecules through passive and active absorption, in this case, the selection of a suitable carrier molecule that must be biodegradable is very important. Biodegradable polymers have proven to be the most promising potential for building anticancer drug delivery systems and can be classified based on the source consisting of synthetic polymers and natural polymers $[1,2,6]$.

One type of polymer being developed at this time is chitosan; chitosan is a polymer derived from the distillation process of chitin which is widely found in invertebrates, especially crustaceans, such as crabs, crabs, and shrimp, has mucoadhesive properties, biodegradable, biocompatible, low immunogenicity and Non-toxic makes this polymer widely used in biomedicine and pharmaceuticals, besides that it is also a strong nucleophile and has a lone pair of electrons from the amine group making chitosan cationic. Alginate is a polymer whose main components come from brown algae, such as sargassum, durvillaea, macrocystis, and ascophyllum. There are two types of monomers in alginic acid, namely $\beta$-D-mannopyranosyl uronic and $\alpha$-Dmannopyranosyl uronic acid-L-glucopyranosil uronate, which causes colloidal, hydrophilic and gel-forming properties, so it is widely used as a thickening agent, emulsifier, and stabilizer in pharmaceutical preparations [7-10]. Combination anionic chitosan and alginate will form cross-links that maximize targeting by regulating encapsulation and release rate as well as excellent and proven mucoadhesive properties. can be well received by the body, improve encapsulation efficiency [11-13] and is known to increase absorption and cellular uptake by widening the narrow film on the preparation [10,14,15].

The nanoparticle formulation based on the combination of chitosan alginate can produce a significant difference in the healing process of cancer therapy compared to the single base. But in this combination the selection of the appropriate method is very important to achieve the formula results with the desired targeting location. The purpose of this review article is to provide a comprehensive view of the potential of nanoparticle targeted delivery systems from a combination of chitosan and alginate-based for cancer therapy.

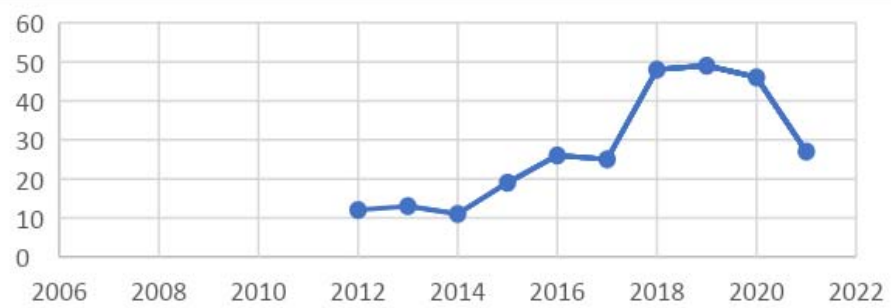

Fig. 1: Distribution of nanoparticle chitosan alginate articles based on the year of publication (self-made) 


\section{METHODS}

This article is based on the results of previous research journals collected from the Google Scholar, Scopus, PubMed and ScienceDirect sites using the keywords chitosan, alginate, targeted drug delivery for cancer, nanoparticle chitosan alginate. With the inclusion criteria, only English-language journals, journals published in the last $10 \mathrm{y}$, relevant to based chitosan and alginate formulations. Meanwhile, the exclusion criteria were journals on pharmacological properties and bioactivity, food and cosmetics, the distribution of articles based on the year of publication can be seen in fig. 1, and for the flowchart of the methodology can be seen in fig. 2 .

307 articles selected for initial screening

Excluded $(\mathbf{n}=39)$

Reviews $(n=39)$

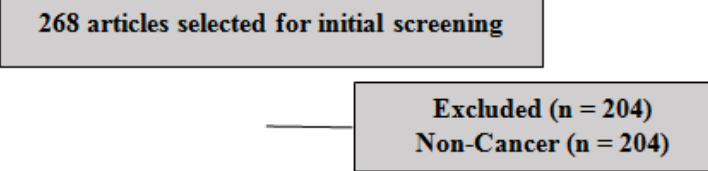

Final Articles

Included $(n=64)$

Fig. 2: Flowchart of the literature search (self-made)

\section{Chemical structure and properties of chitosan and alginate}

\section{Chitosan}

Chitosan is a biological polysaccharide with cationic properties, a compound having the chemical formula poly(1,4)-2-amino-2-dioxyD-glucose) which can be produced from the hydrolysis of chitin using a strong base (deacetylation process) [16] found in crustacean shells, exoskeletons of arthropods, insects, and fungal cell walls. The elements that make up chitosan are almost the same as the elements $\mathrm{C}, \mathrm{H}, \mathrm{N}, \mathrm{O}$ and other elements, which are used as very promising nanomaterials with wide medical applications $[11,12,16]$ and is an abundant biopolymer because it is obtained from From its structure, chitosan is a representative polysaccharide, positively charged amine group consisting of $\mathrm{N}$-acetyl-D-glucosamine (GlcNAc) and Dglucosamine (GlcN) which gives cationic character at physiological $\mathrm{pH}$ [17-19]. This nanomaterial has unique properties, namely resistance to mechanical stress, nontoxic, mucoadhesion, biocompatibility, biodegradability, and bioactivity $[16,20,21]$. Because of its nature that can be degraded by internal enzymes such as lysozyme and chitosanase so as to obtain oligosaccharides and monosaccharides which can then be easily absorbed by the body [22]

However, chitosan has low solubility and poor mechanical properties $[19,25]$ but can form salts with inorganic acids and organic acids such as hydrochloric acid, glutamic acid, acetic acid and lactic acid. When chitosan dissolves, the amine group is protonated and the charge becomes positive [24]. To cover these deficiencies, modifications have been developed $[27,28]$, such as the use of amino and hydroxyl groups to produce derivatives that have a high degree of solubility $[29,30]$. So now it has been widely used in biomedical and pharmaceutical applications such as tissue engineering, wound healing, drug delivery systems, and cosmetic products [29-33]. The active ingredients combined in the matrix must have good solubility in chitosan, because it greatly affects the speed of drug release. These polymers can be used alone or in combination with other polymers to obtain better drug release [34].

\begin{abstract}
Alginate
Alginate is an anionic copolymer obtained from the extraction of brown algae algynophyt, from Phaeophyceae that produce alginates, including macrocystis, Ecklonia, Fucus, lessonia and sargassum, which contain calcium, potassium, sodium ions [36,37] consists of 1,4-linked units of-D-mannuronic acid (M) and-L-glucuronic acid (G) arranged in a clockwise direction [37]. To extract alginate from algae, mineral acid is used to remove contaminants and produce insoluble alginic acid, to dissolve it is neutralized with alkalis such as sodium hydroxide or sodium carbonate to form sodium alginate [38]. In the formation of sodium alginate gel, there is a replacement reaction of more than $35 \% \mathrm{Na}^{+}$cations with $\mathrm{Ca} 2{ }^{+}$which stops the molecular shift. The active ingredients combined in the matrix must have good solubility in chitosan, because it greatly affects the speed of drug release. These polymers can be used alone or in combination with other polymers to obtain better drug release [34].
\end{abstract}

\section{Methods for constructing nanoparticle-based chitosan/alginate} targeted drug delivery

The cationic nature of chitosan, which is able to increase adhesion through electrostatic interactions of the mucosal surface, which has a negative charge is one of the most prominent characteristics and has been proven to be an efficient drug carrier to target cells. However, the most significant drawback is that it is only able to dissolve in acidic media, so it is important to make modifications to cover this deficiency. Several modification methods can be carried out for the manufacture of nanoparticles based on a combination of chitosan and alginate. Methods for constructing nanoparticle Based chitosan and alginate can be seen in fig. 3 .

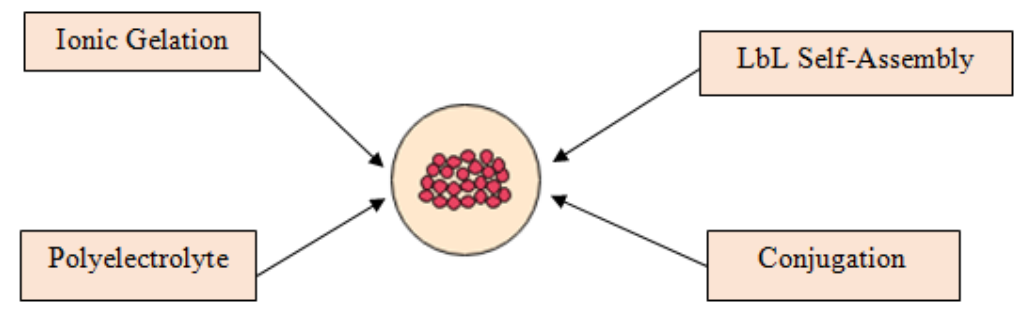

Fig. 3: Methods for constructing nanoparticle based chitosan and alginate (self-made) 


\section{Ionic gelation}

There are two types of ionic crosslinking: first, the manufacturing process is simple, does not use organic solvents or high temperatures, and does not involve chemical interactions. These benefits make this procedure effective for thermolabile drugs. Ionic crosslinking is carried out due to the interaction between positively charged chitosan and negatively charged macromolecules or anionic crosslinking agents. An acid solution of chitosan was prepared, together with stirring and sonication, and the ionic crosslinker was applied dropwise. Second, through chemical interactions between crosslinking agents, primary amine groups, chitosan nanoparticles are formed. Glutaraldehyde, formaldehyde, vanillin, and genipine are common crosslinkers [39].

Ionic gelation method in the process of making nanoparticles is widely used because the process is simple, does not need to use organic solvents and can be controlled easily [40]. Behind these advantages, this method also has disadvantages, namely poor stability under acidic conditions and difficult to trap drugs with high molecular weights [41].

\section{LbL self-assembly}

Layer by Layer (LbL) with electrostatic assembly is often used in surface modification of some materials $[41,42]$. This technique has seen the application of two-dimensional and three-dimensional selfconstructed structures that are nanostructured and easily adaptable [44]. Due to its compatibility with highly organized construction materials and its high versatility, the LbL deposition method is used to construct new biomaterials and has seen promising applications in the biological field [31, 43-45].

The use of LbL assembly with different standard tools and procedures and different processing requirements related to substrates such as porous membranes, particles and biological materials used in its development, including dipping, dewetting, rollto-roll, centrifugation, creaming, calculated saturation, immobilization, rotating, high gravity, spraying, atomization, electrodeposition, magnetic assembly, electrical connection, filtration, fluidics, and fluidized bed fluid. Currently there is a growing realization that the assembly method not only determines the process properties (such as time, scalability, and manual intervention) but also directly affects the physicochemical properties of the film such as thickness, intralayer homogeneity. The advantages of this method are that the process is cheaper than other methods and the percentage of success is high. But behind these advantages, this method has a big challenge because the process occurs without human intervention, so it is important to know how to regulate and maintain the formation of directed supramolecules as desired [47-62].

\section{Polyelectrolyte}

Polysaccharides are an interesting type of polymer found in nature. They often allow a high degree of hydration, are biocompatible, and are often biodegradable [48]. Complex Polyelectrolytes (PEC) are formed from solutions that carry two polyelectrolytes. The formation of PEC is caused by intense coulomb interactions between polyelectrolytes of opposite strength to each other. The formation of this complex results in the charge neutralization of the polymer. Generally, the complex obtained will precipitate or leave the solution to produce a rich and complex liquid process (coacervate). An important driving force for the formation of PEC is the increase in entropy caused by the release of these low molecular weight counterions into the medium. While PEC formation is responsible for electrostatic interactions between the complementary ionic groups of polyelectrolytes, hydrogen bonding and hydrophobic interactions also contribute to the complexity $[62,63]$.

This method is used to overcome the weakness of chitosan properties; materials that have a carboxyl group are used so that they can form polyanones, for example, pectin and alginate. However, obstacles. The amino group in N-glucosamine chitosan, which is positively charged in an acidic environment forms a basic polysaccharide or polycation. Ionic interactions that occur between polyanions (alginate) and polycations (chitosan) form the PEC complex. In addition, other interactions are formed between amino and carboxyl groups, such as hydrogen and covalent bonds formed using conjugation chemistry. The combination of chitosan and alginate is able to overcome the lack of polysaccharides and expand their benefits [65].

\section{Conjugation}

In the chitosan molecule there are $\mathrm{C} 6-\mathrm{OH}$ and $\mathrm{C} 2-\mathrm{NH} 2$ groups which can be used to add other groups with different molecular designs. This modification is able to improve physical and chemical properties and expand its benefits and applications in various fields [66]. The functional groups $\mathrm{C} 3-\mathrm{OH}, \mathrm{C} 2-\mathrm{NH} 2, \mathrm{C} 6-\mathrm{OH}$, amines and glycosides exist in chitosan. Acetyl-amino bonds and glycosidic bonds are not easily broken, making them stable [63]. Examples of other molecular groups that can be added to chitosan are alginate, alginate having an OH-group (anion) capable of being conjugated with chitosan which has a cationic group to form a complex bond [65].

\section{Functionalization strategies of nanoparticle based chitosan and} alginate for cancer targeting

Cancer targeting therapy is able to increase therapeutic efficacy with low side effects, because active compounds can accumulate at the tumor site and are able to recognize differences between normal cells and cancer cells [65-69]. This strategy can be divided into two mechanisms: passive targeting and active targeting.

\section{Passive targeting}

Passive targeting or so-called Enhanced Permeability and Retention (EPR) has the effect of increasing permeability and retention allowing nano-sized carriers to be explicitly distributed penetrate cancer cells through endocytosis and increase the number of drugs acting on cells [67] which is certainly one way to make therapy more efficient [68]. diameter of $<100 \mathrm{~nm}$ with a hydrophilic surface to avoid increased drug targeting and improve drug circulation in the body, this measure affects the amount and kinetics of accumulation of nanomaterials in tumor cells which is expected to be smaller than the cutoff proportion in neovascularization [67]. In addition, under the microenvironment the $\mathrm{pH}$ of tumor tissue is lower than normal tissue, so it is possible to combine chitosan with alginate which is responsive to low $\mathrm{pH}$, a hydrophobic substrate at a physiological $\mathrm{pH}$ of 7.4 becomes hydrophilic at a pH below 6.3 due to protonation during the drug release process triggered by $\mathrm{pH}$ [69].

\section{Active targeting}

Active targeting used for tumor accuracy and delivery efficiency, requiring affinity-based identification, retention, and facilitated uptake of target cells [70]. This targeting is also known as ligandreceptor conjugation, antigen-antibody, and other forms of molecular recognition to DDS to obtain targeted delivery to specific cells, tissues, or organs [71]. The interaction between the ligand and the receptor will increase the absorption of the drug-containing nanoparticles and increase the therapeutic efficacy [67]. Wicaksono et al. reported that the combination of chitosan and alginate together Ribosome-inactivating protein (RIP)It has been used successfully in the treatment of breast cancer by oral administration. And it has also been proven that the Ch/Alg folic acid conjugate is able to perform a better antitumor therapeutic effect than the free drug because of the selective affinity of $\mathrm{Ch} / \mathrm{Alg}$ to intestinal cells [77, 78]. Gascon et al. developed modified CXCL12-conjugated Ch/Alg nanoparticles for the treatment of brain and spinal cancer because the IL-13RA2 receptor (also known as cluster of differentiation $213 \mathrm{~A} 2$, is a membrane-bound protein is highly expressed in glioblastoma cancer tissue and is not present in normal brain tissue [74]. CXCL12 conjugated into nanoparticles was able to significantly increase drug accumulation at the cancer site, thereby enhancing the therapeutic effect. 
Table 1: Strategy targeting nanoparticle based chitosan and alginate cancer active

\begin{tabular}{|c|c|c|c|c|}
\hline \multirow[t]{4}{*}{ Active } & Ligand type & Ligand & Receptor/Targeting site & Ref. \\
\hline & Protein & Ribosome-inactivating protein & rRNA N-glycosidase & [64] \\
\hline & & CXCL12 & IL-13RA2 & {$[74]$} \\
\hline & Vitamin & Folic acid & Folic Acid Receptors & {$[68-71]$} \\
\hline \multirow[t]{5}{*}{ Passive } & Conditions & Function & Molecule & Ref. \\
\hline & pH Responsive & $\begin{array}{l}\text { The drug delivery system remains stable in the } \\
\text { circulation and releases the drug in response to } \mathrm{pH}\end{array}$ & 5-Aminolevulinic acid & [9] \\
\hline & & at certain tissue locations & Boric Acid & [66] \\
\hline & temperature & Release the drug to its temperature responsive & $\mathrm{TiO} 2$ and $\mathrm{Fe} 304$ & {$[72,73]$} \\
\hline & $\begin{array}{l}\text { Magneto } \\
\text { Responsive }\end{array}$ & $\begin{array}{l}\text { Targeted delivery to a specific site via an external } \\
\text { magnetic field. }\end{array}$ & $\mathrm{Fe} 304$ & [77] \\
\hline
\end{tabular}

Humans have a body built with interconnected signals between organs and cells so great effort is needed in studying the deep mysteries associated with the signals of the human body [81, 82]. It has previously been determined that various receptors in the body can be developed in an effort to target drugs $[83,84]$. There are various kinds of compounds used in the delivery of targeted drugs, including glucose, peptides and other types of biological molecules [83].
Cancer targeting therapy is able to increase therapeutic efficacy with low side effects, because the active compounds can accumulate at the tumor site and are able to recognize differences between normal cells and cancer cells [84-88]. Some other examples of nanoparticle combinations based of Chitosan and Alginate (Ch/Alg) nanoparticles designed in dosage formulations for targeted cancer therapy are presented in table 1.

Table 2: Targeted drug delivery of nanoparticle based $\mathrm{Ch} / \mathrm{Alg}$ for cancer therapy

\begin{tabular}{|c|c|c|c|c|c|c|c|}
\hline Agents of drug & $\begin{array}{l}\text { Size } \\
(\mathrm{nm})\end{array}$ & Methode & $\begin{array}{l}\text { Strategies of } \\
\text { cancer-targeting }\end{array}$ & Effect & Cell line & $\begin{array}{l}\text { Cancer } \\
\text { type }\end{array}$ & Ref \\
\hline M. Jalapa L & 130.7 & Active & $\begin{array}{l}\text { Conjugated with } \\
\text { anti Ep-CAM } \\
\text { antibody }\end{array}$ & Enhance Cytotoxicities, less selectivity & T47D & $\begin{array}{l}\text { Breast } \\
\text { Cancer }\end{array}$ & {$[64$} \\
\hline $\begin{array}{l}\text { Iron saturated } \\
\text { bovine lactferrin }\end{array}$ & 322 & Passive & Polyelectrolyte & $\begin{array}{l}\text { Improved antitumor by internalizing and } \\
\text { regulating micro-RNA expression }\end{array}$ & MDA-MB-231 & $\begin{array}{l}\text { Breast } \\
\text { Cancer }\end{array}$ & {$[89$} \\
\hline $\begin{array}{l}\text { Curcumin } \\
\text { diglutaric acid }\end{array}$ & $\begin{array}{l}212- \\
552\end{array}$ & Passive & $\begin{array}{l}\text { Enhanced cellular } \\
\text { uptake }\end{array}$ & $\begin{array}{l}\text { The superior inhibitory effects on the } \\
\text { viability of cancer cells and higher } \\
\text { cytotoxicity }\end{array}$ & $\begin{array}{l}\text { MDA-MB-23, } \\
\text { HepG2 and } \\
\text { Caco-2 }\end{array}$ & $\begin{array}{l}\text { Breast } \\
\text { Cancer }\end{array}$ & {$[90$} \\
\hline Doxorubicin & $\sim 80$ & Passive & $\begin{array}{l}\text { Enhanced cellular } \\
\text { uptake }\end{array}$ & $\begin{array}{l}\text { Have high concentration to induce a } \\
\text { therapeutic effect breast cancer cell line }\end{array}$ & 4T1 murine & $\begin{array}{l}\text { Breast } \\
\text { Cancer }\end{array}$ & {$[91]$} \\
\hline Curcumin & $\sim 200$ & Passive & $\begin{array}{l}\text { Magneto- } \\
\text { responsive }\end{array}$ & $\begin{array}{l}\text { Eenhanced the biocompatibility and can be } \\
\text { controlled to specified targeting }\end{array}$ & MCF-7 & $\begin{array}{l}\text { Breast } \\
\text { Cancer }\end{array}$ & {$[77$} \\
\hline $\begin{array}{l}5- \\
\text { Aminolevulinic } \\
\text { acid }\end{array}$ & 115 & Passive & $\begin{array}{l}\text { Depending on the } \\
\text { pH of the } \\
\text { environment }\end{array}$ & $\begin{array}{l}\text { Improved the efficacy of the 5-ALA for } \\
\text { photosensitizer. }\end{array}$ & HeLa Cell & $\begin{array}{l}\text { Cervical } \\
\text { Cancer }\end{array}$ & [9] \\
\hline Methyl oxide & 21 & Passive & $\begin{array}{l}\text { Enhanced cellular } \\
\text { uptake }\end{array}$ & $\begin{array}{l}\text { Exhibit better protein absorption capability } \\
\text { suitable for cell attachment and growth }\end{array}$ & $\begin{array}{l}\text { UC6 (Bladder } \\
\text { tumor cell line), } \\
\text { MG-63 }\end{array}$ & $\begin{array}{l}\text { Bladder } \\
\text { Cancer }\end{array}$ & {$[78$} \\
\hline $\begin{array}{l}\text { Temozolomide } \\
\text { anddoxorubicin }\end{array}$ & $\begin{array}{l}70- \\
120\end{array}$ & Active & $\begin{array}{l}\text { Folic acid receptor- } \\
\text { based endocytosis }\end{array}$ & $\begin{array}{l}\text { Decrease tumor cell line, increase its } \\
\text { absorption and selectivity }\end{array}$ & $\begin{array}{l}\text { HeLa and } \\
\text { NIH/3T3 Cell }\end{array}$ & $\begin{array}{l}\text { Cervical } \\
\text { Cancer }\end{array}$ & {$[75$} \\
\hline 5-Fluorouracil & 130 & Active & Folic acid & $\begin{array}{l}\text { Improved antiproliferative activity of } \\
\text { cancer cells }\end{array}$ & HCT116 & $\begin{array}{l}\text { Colon } \\
\text { Cancer }\end{array}$ & {$[76$} \\
\hline CXCL12 & $\begin{array}{l}133- \\
297\end{array}$ & Active & Conjugated ligand & $\begin{array}{l}\text { Control GBM cell invasion without } \\
\text { enhancing their proliferation }\end{array}$ & GBM cells & $\begin{array}{l}\text { Brain } \\
\text { Cancer }\end{array}$ & {$[74$} \\
\hline$\alpha$-mangostin & 192 & Active & $\begin{array}{l}\text { Folic acid receptor- } \\
\text { based endocytosis }\end{array}$ & $\begin{array}{l}\text { Improved antiproliferative activity of } \\
\text { cancer cells }\end{array}$ & HCT116 & $\begin{array}{l}\text { Colon } \\
\text { Cancer }\end{array}$ & {$[73$} \\
\hline$\alpha$-mangostin & 100 & Active & Folic acid & $\begin{array}{l}\text { Improved antiproliferative activity of } \\
\text { cancer cells }\end{array}$ & HCT116 & $\begin{array}{l}\text { Colon } \\
\text { Cancer }\end{array}$ & {$[72$} \\
\hline Boric acid & 136 & Passive & $\begin{array}{l}\text { Depending on the } \\
\mathrm{pH} \text { of the } \\
\text { environment }\end{array}$ & $\begin{array}{l}\text { Significantly reduce the cytotoxicity by } 12 \text { - } \\
\text { fold and increase the killing efficacy of } \\
\text { tumor cells }\end{array}$ & SAS Cell & $\begin{array}{l}\text { Oral } \\
\text { Cancer }\end{array}$ & {$[66$} \\
\hline
\end{tabular}

Based on the data shown in table 2. Nanoparticles can enter cells through direct diffusion mechanisms or adhesive interactions, phagocytosis, and micropinocytosis. Chemical properties, such as shape, particle size, surface charge, and composition. In previous studies, smaller nanoparticles were easier to enter into cells through endocytosis or diffusion mechanisms, while larger nanoparticles were more likely to penetrate into cells through phagocytosis mechanisms [92]. Cells incubated in the presence of Ch/Alg complex and $\mathrm{Ch} / \mathrm{Alg}$ filled with 5-ALA showed higher emissions compared to positive controls. As reported in previous studies, the higher emission of $\mathrm{Ch} / \mathrm{Alg}$ is predicted to come from the surface properties of the nanoparticles which can increase the interaction with cell membranes accompanied by higher absorption and accumulation of
5-ALA [9, 92]. This value could be attributed to the decreased capacity of cells to degrade Chi/Alg carriers resulting in lower conversion rates and poor accumulation of Protoporphyrin IX in cells $[9,93]$.

$\mathrm{Ch} / \mathrm{Alg}$ in the form of nanoparticles is very effective as a carrier for cancer drugs can be seen in table 2. However, there are several things that need to be considered in therapy, namely the increase in cytotoxicity, cell uptake, circulation time, and the level of selectivity to normal cells. This is associated with an increase in cytotoxicity in the form of effectiveness and efficiency of nanoparticles which can be done by optimizing their targeting strategies both actively and passively. Nanoparticles can bind to the physiological $\mathrm{pH}$ of the body 
as short peptides that are both hydrophilic and hydrophobic, this increase in cellular uptake causes large membrane damage, which can penetrate cell membranes at low micromolar concentrations by increasing drug concentrations in cells. Drug concentration in cancer cells will increase cytotoxicity. The value of this effective diffusion coefficient is associated with the electrostatic interaction between positively charged protein/peptide, and negatively charged alginate core that composes $\mathrm{Ch} / \mathrm{Alg}$ nanoparticles.

Ch/Alg nanoparticle technology has various modifications in drug development efforts to increase drug accumulation in cancer cells [72, 94-98], mobile uptake [99, 100], cytotoxicity [101] and selectivity to normal cells [102-104]. Taking into account the EPR effect and the active targeting portion, Ch/Alg-based nanoparticles will achieve all of these goals. $\mathrm{Ch} /$ Alg nanoparticles can work by delivering anticancer drugs to all cancer cells, which are widely used representing all types of cancer. Our objective research shows that chitosan-based nanoparticle technology synergizes the overall impact of the effects of EPR and active targeting components in delivering anticancer drugs to cancer cells. Decrease in nanoparticle size increases drug solubility and stability [105-108] and surface charge of nanoparticles, enhances drug protection in blood circulation $[33,109]$ and increases drug absorption in cancer cells $[33,66,100]$ (table 2). This modification of the $\mathrm{Ch} / \mathrm{Alg}$ combination will maximize other cancer cell-specific characteristics such as the $\mathrm{pH}$ gradient [110-112], temperature and the redox [30]. Therefore, the formulation of a nanoparticle based combination of chitosan and alginate is an option in overcoming the disadvantages of poor solubility in water and low selectivity for drug delivery to target cells.

\section{CONCLUSION}

Therapy using nanoparticles based combination of chitosan and alginate (Ch/Alg) can be applied to anticancer drugs to any cancer cells, such as for breast cancer, cervical cancer, bladder cancer, colon cancer, brain cancer, and oral cancer, working by increasing cytotoxicity and increasing drug accumulation, selectivity, and efficacy. The combination of cationic chitosan and anionic alginate forming strong cross-links showed good mucoadhesive properties, higher resistance to low $\mathrm{pH}$ and high-efficiency encapsulation without showing any obvious cytotoxicity. $\mathrm{Ch} / \mathrm{Alg}$ can overcome the shortcomings of the active substance such as its rapid release process and the required active ingredient is lower than that required to enter the cancer target cells so as to minimize side effects of the drug, by providing drug-induced release. in response to various stimuli that are well suited to the intended purpose such as $\mathrm{pH}$ stimuli, redox gradients, light, temperature, and magnetism. Cancer therapy with nanocarrier combinations of chitosan and alginate offer great opportunities in the treatment of various types of cancer.

\section{FUNDING}

Nil

\section{AUTHORS CONTRIBUTIONS}

All the authors have contributed equally.

\section{CONFLICT OF INTERESTS}

The authors declare that we have no conflicts of interest in this work.

\section{REFERENCES}

1. Seidi K, Jahanban Esfahlan R, Monhemi H, Zare P, Minofar B, Daei Farshchi Adli A, Farajzadeh D, Behzadi R, Mesgari Abbasi M, Neubauer HA, Moriggl R, Zarghami N, Javaheri T. NGR (AsnGly-Arg)-targeted delivery of coagulase to tumor vasculature arrests cancer cell growth. Oncogene. 2018;37(29):3967-80. doi: 10.1038/s41388-018-0213-4, PMID 29662195.

2. Kunduru KR, Basu A, Domb AJ. Biodegradable polymers: medical applications biodegradable polymers. Med Appl. 2018;10:1-22.

3. Paques JP, van der Linden E, van Rijn CJ, Sagis LM. Preparation methods of alginate nanoparticles. Adv Colloid Interface Sci. 2014;209:163-71. doi: 10.1016/j.cis.2014.03.009, PMID 24745976.
4. Parvanian S, Mostafavi SM, Aghashiri M. Multifunctional nanoparticle developments in cancer diagnosis and treatment. Sens Bio Sens Res. 2017;13:81-7. doi: 10.1016/j.sbsr.2016.08.002.

5. Bahrami B, Hojjat Farsangi MF, Mohammadi H, Anvari E, Ghalamfarsa G, Yousefi M, Jadidi Niaragh F. Nanoparticles and targeted drug delivery in cancer therapy. Immunol Lett. 2017;190:64-83. doi: 10.1016/j.imlet.2017.07.015, PMID 28760499.

6. Doppalapudi S, Jain A, Domb AJ, Khan W. Biodegradable polymers for targeted delivery of anti-cancer drugs. Expert Opin Drug Deliv. 2016;13(6):891-909. doi: 10.1517/17425247.2016.1156671, PMID 26983898.

7. Kumar MN, Muzzarelli RA, Muzzarelli C, Sashiwa H, Domb AJ. Chitosan chemistry and pharmaceutical perspectives. Chem Rev. 2004;104(12):6017-84. doi: 10.1021/cr030441b, PMID 15584695.

8. Gavini E, Rassu G, Haukvik T, Lanni CA, Racchi M, Giunchedi P. Mucoadhesive microspheres for nasal administration of cyclodextrins. J Drug Target. 2009;17(2):168-79. doi: 10.1080/10611860802556842, PMID 18985506.

9. Di Martino A, Pavelkova A, Postnikov PS, Sedlarik V. Enhancement of 5-aminolevulinic acid phototoxicity by encapsulation in polysaccharides based nanocomplexes for photodynamic therapy application. J Photochem Photobiol B. 2017;175:226-34. doi: 10.1016/j.jphotobiol.2017.08.010. PMID 28915492.

10. Nagpal K, Singh SK, Mishra DN. Chitosan nanoparticles: A promising system in novel drug delivery. Chem Pharm Bull. 2010;58(11):1423-30. doi: 10.1248/cpb.58.1423.

11. Sheng J, Han L, Qin J, Ru G, Li R, Wu L, Cui D, Yang P, He Y, Wang J. N-trimethyl chitosan chloride-coated PLGA nanoparticles overcoming multiple barriers to oral insulin absorption. ACS Appl Mater Interfaces. 2015;7(28):15430-41. doi: 10.1021/acsami.5b03555, PMID 26111015.

12. Senel S, McClure SJ. Potential applications of chitosan in veterinary medicine. Adv Drug Deliv Rev. 2004;56(10):146780. doi: 10.1016/j.addr.2004.02.007, PMID 15191793.

13. Motiei M, Kashanian S, Lucia LA, Khazaei M. Intrinsic parameters for the synthesis and tuned properties of amphiphilic chitosan drug delivery nanocarriers. J Control Release. 2017;260:213-25. doi: 10.1016/j.jconrel.2017.06.010, PMID 28625671.

14. Tiyaboonchai W. Chitosan nanoparticles: A promising system for drug delivery. Naresuan Univ J. 2003;11:51-66.

15. Sun Y, Wan A. Preparation of nanoparticles composed of chitosan and its derivatives as delivery systems for macromolecules. J Appl Polym Sci. 2007;105(2):552-61. doi: 10.1002/app.26038.

16. Hargono H, Abdullah AA, Sumantri I. Pembuatan Kitosan dari limbah cangkang udang serta Aplikasinya dalam Mereduksi kolesterol lemak kambing. Reaktor. 2008;12(1):53. doi: 10.14710/reaktor.12.1.53-57.

17. Wang Y, Jia Y, Yan L, Fu J, Hao M, Chen W, Yao B, Zhao P, Zhou Z. Clusterin and Neuropilin-2 as potential biomarkers of tumor progression in benzo[a]pyrene-transformed 16HBE cells xenografted nude mouse model. Chem Biol Interact. 2017;275:145-51. doi: 10.1016/j.cbi.2017.08.002, PMID 28784314 .

18. Hardy A, Seguin C, Brion A, Lavalle P, Schaaf P, Fournel S, BourelBonnet L, Frisch B, De Giorgi M. $\beta$-cyclodextrin-functionalized chitosan/Alginate compact polyelectrolyte complexes (CoPECs) as functional biomaterials with anti-inflammatory properties. ACS Appl Mater Interfaces. 2018;10(35):29347-56. doi: 10.1021/acsami.8b09733, PMID 30107127.

19. Prabaharan M. Review paper: chitosan derivatives as promising materials for controlled drug delivery. J Biomater Appl. 2008;23(1):5-36. doi: 10.1177/0885328208091562, PMID 18593819.

20. Diebold Y, Jarrin M, Saez V, Carvalho EL, Orea M, Calonge M, Seijo B, Alonso MJ. Ocular drug delivery by liposome-chitosan nanoparticle complexes (LCS-NP). Biomaterials. 2007;28(8):1553-64. doi: 10.1016/j.biomaterials.2006.11.028, PMID 17169422. 
21. Kean T, Thanou M. Biodegradation, biodistribution and toxicity of chitosan. Adv Drug Deliv Rev. 2010;62(1):3-11. doi: 10.1016/j.addr.2009.09.004, PMID 19800377.

22. Woraphatphadung T, Sajomsang W, Rojanarata T, Ngawhirunpat T, Tonglairoum P, Opanasopit P. Development of chitosan-based pHsensitive polymeric micelles containing curcumin for colontargeted drug delivery. AAPS PharmSciTech. 2018;19(3):9911000. doi: 10.1208/s12249-017-0906-y, PMID 29110292.

23. Cappello V, Marchetti L, Parlanti P, Landi S, Tonazzini I, Cecchini M, Piazza V, Gemmi M. Ultrastructural characterization of the lower motor system in a mouse model of krabbe disease. Sci Rep. 2016;6(1):1. doi: 10.1038/s41598016-0001-8. PMID 28442746.

24. Aranaz I. Functional characterization of chitin and chitosan. Curr Chem Biol. 2009;3:203-30.

25. Zhao X, Zhou L, Li Q, Zou Q, Du C. Biomimetic mineralization of carboxymethyl chitosan nanofibers with improved osteogenic activity in vitro and in vivo. Carbohydr Polym. 2018;195:22534. doi: 10.1016/j.carbpol.2018.04.090, PMID 29804972.

26. Yan L, Crayton SH, Thawani JP, Amirshaghaghi A, Tsourkas A, Cheng Z. A pH-responsive drug-delivery platform based on glycol chitosan-coated liposomes. Small. 2015;3711(37):48704. doi: 10.1002/smll.201501412, PMID 26183232.

27. Ali A, Ahmed S. A review on chitosan and its nanocomposites in drug delivery. Int J Biol Macromol. 2018;109:273-86. doi: 10.1016/j.ijbiomac.2017.12.078, PMID 29248555.

28. Ho DK, Sarah BF, Alexander T, Emmanuel RD, Chiara S, Franziska LHo DK, Frisch S, Biehl A, Terriac E, De Rossi C, Schwarzkopf K, Lautenschlager F, Loretz B, Murgia X, Lehr CM. Farnesylated glycol chitosan as a platform for drug delivery: synthesis, characterization, and investigation of mucus-particle interactions. Biomacromolecules. 2018;19(8):3489-501. doi: 10.1021/acs.biomac.8b00795, PMID 29989799.

29. Xiao B, Veronicka B, Komal Q Bessi D, Alexandria D, Myron RXiao B, Chen Q, Zhang Z, Wang L, Kang Y, Denning T, Merlin D. TNF $\alpha$ gene silencing mediated by orally targeted nanoparticles combined with interleukin-22 for synergistic combination therapy of ulcerative colitis. J Controlled Release. 2018;287:235-46. doi: 10.1016/j.jconrel.2018.08.021, PMID 30107214.

30. Martinez M, Rodriguez B, Guillermo GA, Isabel H, Corma $M$, Avelino B, Martinez Martinez M, Rodriguez Berna G, Gonzalez Alvarez I, Hernandez MJ, Corma A, Bermejo M, Merino V, Gonzalez-Alvarez M. Ionic hydrogel based on chitosan crosslinked with 6-phosphogluconic trisodium salt as a drug delivery system. Biomacromolecules. 2018;19(4):1294-304. doi: 10.1021/acs.biomac.8b00108, PMID 29537830.

31. Yan Q, Chen X, Gong H, Qiu P, Xiao X, Dang S, Hong A, Ma Y. Delivery of a TNF- $\alpha$-derived peptide by nanoparticles enhances its antitumor activity by inducing cell-cycle arrest and caspasedependent apoptosis. FASEB J. 2018:fj201800377R. doi: 10.1096/fj.201800377R. PMID 30161002.

32. Toxicol C, Res A. Formulation, characterization, and herbal drug delivery applications of ethosome, Transfersome, and Transethosome Luthfia. Indonesian J Pharm. 2020;20:185-95.

33. Li J, Chao L, Jiarui L, Jun L, Sun J, Tiantian WLi J, Cai C, Sun T, Wang L, Wu H, Yu G. Chitosan-based nanomaterials for drug delivery. Molecules. 2018;23(10):1-26. doi: 10.3390/molecules23102661, PMID 30332830.

34. Heng PWS. Compaction of coated multi-particulates. Asian J Pharm Sci. 2016;11(1):12-3. doi: 10.1016/j.ajps.2015.10.010.

35. Widyastuti S. Alginate content of the seaweeds grown in coastal zone of Lombok extracted by two extraction methods. J Teknologi Pertanian. 2009;10:144-52.

36. Ode I, Wasahua J. Jenis-jenis alga coklat potensial di perairan pantai desa hutumuri pulau ambon. Agrikan: Jurnal Agribisnis Perikanan Agrikan: J Agro Fish. 2014;7(2):39. doi: 10.29239/j.agrikan.7.2.39-45.

37. Li J, He J, Huang Y. Role of alginate in antibacterial finishing of textiles. Int J Biol Macromolecules. 2017;94(A):466-73. doi: 10.1016/j.ijbiomac.2016.10.054, PMID 27771407.

38. Pawar SN, Edgar KJ. Alginate derivatization: Aa review of chemistry, properties and applications. Biomaterials. 2012;33(11):3279-3305. doi: 10.1016/j.biomaterials.2012.01.007, PMID 22281421.
39. Ahmed TA, Aljaeid BM. Preparation, characterization, and potential application of chitosan, chitosan derivatives, and chitosan metal nanoparticles in pharmaceutical drug delivery. Drug Des Devel Ther. 2016;10:483-507. doi: 10.2147/DDDT.S99651, PMID 26869768.

40. Alsmadi MM, Obaidat RM, Alnaief M, Albiss BA, Hailat N. Development, in vitro characterization, and in vivo toxicity evaluation of chitosan-alginate nanoporous carriers loaded with cisplatin for lung cancer treatment. AAPS PharmSciTech. 2020;21(5):1-12191. doi: 10.1208/s12249-020-01735-8, PMID 32661587.

41. Sahatsapan N, Ngawhirunpat $T$, Rojanarata T, Opanasopit $P$, Patrojanasophon P. Catechol-functionalized alginate nanoparticles as mucoadhesive carriers for intravesical chemotherapy. AAPS PharmSciTech. 2020;21(6):1-9212. doi: 10.1208/s12249-020-01752-7, PMID 32737610.

42. Poon Z, Chang D, Zhao X, Hammond PT. Layer-by-layer nanoparticles with a $\mathrm{pH}$-sheddable layer for in vivo targeting of tumor hypoxia. ACS Nano. 2011;5(6):4284-92. doi: 10.1021/nn200876f, PMID 21513353.

43. Chen $Y$, Lin X, Park H, Greever R. Study of artemisinin nanocapsules as anticancer drug delivery systems. Nanomed: Nanotechnol, Biol, Med. 2009;5(3):316-22. doi: 10.1016/j.nano.2008.12.005, PMID 19523432.

44. Costa RR, Mano F, Costa RR. Chem soc rev polyelectrolyte multilayered assemblies. In: Biomedical technologies. Vol. 10. Royal Society of Chemistry; 2014. p. 1-27.

45. Xiao F, Pagliaro M, Xu Y, Liu B. Chem Soc Rev Layer-by-layer assembly of versatile nanoarchitectures with diverse dimensionality : a new perspective for rational construction of multilayer assemblies. Vol. 15. Royal Society of Chemistry; 2014. p. 27-35.

46. Oliveira MB, Hatami J, Mano JF. Coating strategies using layerby-layer deposition for cell encapsulation. Chem Asian J. 2016;11(12):1753-64. doi: 10.1002/asia.201600145, PMID 27213990.

47. Wathoni N, Diah I, Motoyama K, Mohammed A, Cahyanto A, Marline A, Wathoni N, Sari DP, Suharyani I, Motoyama K, Mohammed AFA, Cahyanto A, Abdassah M, Muchtaridi M. Enhancement of $\alpha$-mangostin wound healing ability by complexation with 2-hydroxypropyl- $\beta$-cyclodextrin in hydrogel formulation. Pharmaceuticals (Basel). 2020;13(10):1-16. doi: 10.3390/ph13100290, PMID 33023196.

48. Shim BS, Podsiadlo S, Lilly P, Daniel GA, Ashish L, Jaebom T, Shim BS, Podsiadlo P, Lilly DG, Agarwal A, Lee J, Tang Z, Ho S, Ingle P, Paterson D, Lu W, Kotov NA. Nanostructured thin films made by dewetting method of layer-by-layer assembly. Nano Letters. 2007;7(11):3266-73. doi: 10.1021/nl071245d, PMID 17935371.

49. Sundaram, Sujatha S, Indrea S, Stephanie S, Rendall H, Jack DP, Sundaram S, Sea A, Feldman S, Strawbridge R, Hoopes PJ, Demidenko E, Binderup L, Gewirtz DA. The combination of a potent vitamin D3 analog, EB 1089, with ionizing radiation reduces tumor growth and induces apoptosis of MCF-7 breast tumor xenografts in nude mice. Clinical Cancer Research. 2003;9(6):2350-6. PMID 12796405.

50. Hong X, Li J, Wang M, Xu J, Guo W, Li J, Bai Y, Li T. Fabrication of magnetic luminescent nanocomposites by a layer-by-layer selfassembly approach. Chem Materials. 2004;16(21):4022-4027. doi: $10.1021 / \mathrm{cm} 0494220$.

51. Rydzek G, Gaulthier A, Jierry B, Philippe L, Ponche M, Contal A, Rydzek G, Thomann JS, Ben Ameur N, Jierry L, Mésini P, Ponche A, Contal C, El Haitami AE, Voegel JC, Senger B, Schaaf P, Frisch B, Boulmedais F. Polymer multilayer films obtained by electrochemically catalyzed click chemistry. Langmuir. 2010;26(4):2816-24. doi: 10.1021/la902874k, PMID 19950954.

52. Voigt A, Lichtenfeld H, Sukhorukov GB, Zastrow H, Donath E, Bäumler $\mathrm{H}$, Möhwald $\mathrm{H}$. Membrane filtration for microencapsulation and microcapsules fabrication by layer-bylayer polyelectrolyte adsorption. Ind Eng Chem Res. 1999;38(10):4037-43. doi: 10.1021/ie9900925.

53. Picart C, Lavalle P, Hubert P, Cuisinier FJG, Decher JG, Schaaf P, Voegel JC. Buildup mechanism for Poly poly(L- 
lysine)/hyaluronic acid films onto a solid surface. Langmuir. 2001;17(23):7414-24. doi: 10.1021/la010848g.

54. Richardson JJ, Ejima E, Hirotaka L, Samuel L, Liang K, Senn PRichardson JJ, Ejima H, Lorcher SL, Liang K, Senn P, Cui J, Caruso F. Preparation of nano- and microcapsules by electrophoretic polymer assembly. Angewandte Chemie International Edition Engl. 2013;52(25):6455-8. doi: 10.1002/anie.201302092, PMID 23657949.

55. Iinuma M, Tosa H, Tanaka T, Asai F, Kobayashi Y, Shimano R, Miyauchi K. Antibacterial activity of xanthones from guttiferaeous plants against methicillin-resistant staphylococcus aureus. J Pharm Pharmacol. 1996;48(8):861-5. doi: 10.1111/j.2042-7158.1996.tb03988.x, PMID 8887739.

56. Donath E, Walther D, Shilov VN, Knippel E, Budde A, Lowack K, Helm CA, Mohwald $H$. Nonlinear hairy layer theory of electrophoretic fingerprinting applied to consecutive layer by layer polyelectrolyte adsorption onto charged polystyrene latex particles. Langmuir. 1997;13(20):5294-305. doi: 10.1021/la970090u.

57. Grigoriev DO, Bukreeva T, Mohwald H, Shchukin DG. New method for fabrication of loaded micro- and nanocontainers: emulsion encapsulation by polyelectrolyte layer-by-layer deposition on the liquid core. Langmuir. 2008;24(3):999-1004. doi: 10.1021/la702873f. PMID 18163658.

58. Hoogeveen NG, Stuart MAC, Fleer GJ, Bo MR, Hoogeveen NG, Cohen Stuart MA, Fleer GJ, Bohmer MR. Formation and stability of multilayers of polyelectrolytes. Langmuir. 1996;12(15):3675-81. doi: 10.1021/la951574y.

59. Richardson JJ, Teng D, Bjornmalm M, Gunawan ST, Guo J, Cui J, Franks GV, Caruso F. Fluidized bed layer-by-layer microcapsule formation. Langmuir. 2014;30(33):10028-34. doi: 10.1021/la502176g, PMID 25113552.

60. Thomas IM. Single-layer $\mathrm{TiO}(2)$ and multilayer $\mathrm{TiO}(2)-\mathrm{SiO}(2)$ optical coatings prepared from colloidal suspensions. Applied Optics. 1987;26(21):4688-91. doi: 10.1364/AO.26.004688, PMID 20523426.

61. Schlenoff JB, Dubas ST, Farhat T. Sprayed polyelectrolyte multilayers. Langmuir. 2000;16(26):9968-9. doi: 10.1021/la001312i.

62. Ma L., Cheng M, Jia G, Wang Y, An Q, Zeng X, Shen Z, Zhang Y, Shi F. Layer-by-layer self-assembly under high gravity field. Langmuir. 2012;28(25):9849-56. doi: 10.1021/la301553w, PMID 22639916.

63. Quinñones JP, Peniche H, Peniche C. Chitosan based selfassembled nanoparticles in drug delivery. Polymers. 2018;10(3):1-32. doi: 10.3390/polym10030235, PMID 30966270.

64. Psycha HI, Anindya WS, Sismindari N, Ronny M. Formulation and cytotoxicity of ribosome-inactivating protein Mirabilis jalapa L. nanoparticles using alginate-low viscosity chitosan conjugated with anti-Epcam antibodies in the T47D breast cancer cell line. Asian Pac J Cancer Prev. 2016;4:2277-84.

65. Chen G, Svirskis D, Lu W, Ying M, Huang Y, Wen J. N -trimethyl chitosan nanoparticles and CSKSSDYQC peptide: $\mathrm{N}$-trimethyl chitosan conjugates enhance the oral bioavailability of gemcitabine to treat breast cancer. J Controlled Release. 2018;277:142-53. doi: 10.1016/j.jconrel.2018.03.013.

66. Wu WC, Wang SH, Ou ST, Liu YWH, Liu BH, Tseng FG. Electrosprayed chitosan/alginate/polyvinyl alcohol nanoparticles as boric acid carriers for 10Boron neutron capture therapy. Nanomedicine (Lond). 2020;15(11):1067-77. doi: 10.2217/nnm-2019-0465, PMID 32326875.

67. Yoo J, Park C, Yi G, Lee D, Koo H. Active targeting strategies using biological ligands for nanoparticle drug delivery systems. Cancers. 2019;11(5):1-13. doi: 10.3390/cancers11050640, PMID 31072061.

68. Jee JP, Na JH, Lee S, Kim SH, Choi K, Yeo Y, Kwon IC. Cancer targeting strategies in nanomedicine: design and application of chitosan nanoparticles. Curr Opinion Solid State Materials Science. 2012;16(6):333-42. doi: 10.1016/ j.cossms.2013.01.002.

69. Woraphatphadung $T$, Sajomsang $W$, Rojanarata $T$, Ngawhirunpat T, Tonglairoum P, Opanasopit P. Development of chitosan-based pH-sensitive polymeric micelles containing curcumin for colon-targeted drug delivery. AAPS PharmSciTech. 2018;19(3):991-1000. doi: 10.1208/s12249017-0906-y, PMID 29110292.

70. Navya PN, Kaphle A, Srinivas SP, Bhargava SK, Rotello VM, Daima HK. Current trends and challenges in cancer management and therapy using designer nanomaterials. Nano Convergence. 2019;6(1):1-30:23. doi: 10.1186/s40580-0190193-2, PMID 31304563.

71. Zhong Z, Cai L, Li C. Characterization and targeting ability evaluation of cell-penetrating peptide Lyp-1 modified alginatebased Nnanoparticles. RSC Advances. 2020;10(54):32443-9. doi: 10.1039/D0RA06628A.

72. Mulia K, Singarimbun AC, Krisanti EA. Optimization of chitosan- alginate microparticles for delivery of mangostins to the colon area using box-Behnken experimental design. International Journal of Molecular Sciences. 2020;21(3):1-10. doi: 10.3390/ijms21030873, PMID 32013253.

73. Mulia K, Halimah N, Krisanti K. Effect of alginate composition on profile release and characteristics of chitosan-alginate microparticles loaded with mangosteen extract. AIP Conference Proceedings. 2017;1823:1-8.

74. Gascon S, Solano A, Giraldo EK, Wiam T, Helene B, Gascon S, Giraldo Solano A, El Kheir W, Therriault H, Berthelin P, Cattier B, Marcos B, Virgilio N, Paquette B, Faucheux N, Lauzon MA. Characterization and mathematical modeling of alginate/chitosan-based nanoparticles releasing the chemokine cxclCXCL12 to attract glioblastoma cells. Pharmaceutics. 2020;12(4):1-21. doi: 10.3390/pharmaceutics12040356, PMID 32295255.

75. Di Martino AD, Trusova ME, Postnikov PS, Sedlarik V. Folic acid-chitosan-alginate nanocomplexes for multiple delivery of chemotherapeutic agents. J Drug Delivery Sci Technol. 2018;47:67-76. doi: 10.1016/j.jddst.2018.06.020.

76. Anirudhan TS, Sekhar VCV, Nair SS. Polyelectrolyte complexes of carboxymethyl chitosan/alginate based drug carrier for targeted and controlled release of dual drug. Journal of Drug Delivery Science and Technology. 2019;51:569-82. doi: 10.1016/j.jddst.2019.03.036.

77. Jardim KV, Palomec-Garfias AF, Andrade BYG, Chaker JA, Bao SN, Marquez-Beltran C, Moya SE, Parize AL, Sousa MH. Novel magneto-responsive nanoplatforms based on $\mathrm{MnFe} 204$ Nanoparticles layer-by-layer functionalized with chitosan and sodium alginate for magnetic controlled release of curcumin. Materials Science and Engineering C Mater Biol Appl. 2018;92:184-95. doi: 10.1016/j.msec.2018.06.039, PMID 30184741.

78. Shanmugam BK, Rangaraj S, Subramani K, Srinivasan S, Aicher WK, Venkatachalam R. Biomimetic TiO2-chitosan/sodium alginate blended nanocomposite scaffolds for tissue engineering applications. Materials Science and Engineering C. 2020;110:1-13.

79. Heneka MT, Mcmanus RM, Latz E. Inflammasome signalling in brain function and neurodegenerative disease. Nature Reviews Neuroscience. 2018;19(10):610-21. doi: 10.1038/s41583-0180055-7, PMID 30206330.

80. Kuwako K, Okano H. The LKB1-SIK pathway controls dendrite self-Aavoidance in Purkinje cells report the LKB1-SIK pathway controls dendrite self-avoidance in Purkinje cells. Cell Reports. 2018;24:2808-18.

81. Cardoso AP, Goncalves RM, Antunes JC, Pinto ML, Pinto AT, Castro F, Monteiro C, Barbosa MA, Oliveira MJ. An interferon- $\gamma$ delivery system based on chitosan/poly( $\gamma$-glutamic acid $)$ polyelectrolyte complexes modulates macrophage-derived stimulation of cancer cell invasion in vitro. Acta Biomaterialia. 2015;23:157-71. doi: 10.1016/j.actbio.2015.05.022, PMID 26013040.

82. Wang W, Qiuyu M, Qi Li, Jinbao L, Mo Z, Zheng J, Wang W, Meng Q, Li Q, Liu J, Zhou M, Jin Z, Zhao K. Chitosan derivatives and their application in biomedicine. International Journal of Molecular Sciences. 2020;21(2):1-26. doi: 10.3390/ ijms21020487, PMID 31940963.

83. Wang Z, Sun J, Qiu Y, Li W, Guo X, Li Q, Zhang H, Zhou J, Du Y, Yuan $\mathrm{H}, \mathrm{Hu}$ F, You J. Specific photothermal therapy to the tumors with high EphB4 receptor expression. Biomaterials. 
2015;68:32-41. doi: 10.1016/j.biomaterials.2015.07.058, PMID 26264644 .

84. Shanmuganathan R, Edison TNJI, Lewis Oscar FO, Kumar P, Shanmugam S, Pugazhendhi A. Chitosan nanopolymers: an overview of drug delivery against cancer. International Journal of Biological Macromolecules. 2019;130:727-36. doi: 10.1016/j.ijbiomac.2019.02.060, PMID 30771392.

85. Zhang X, Yang X, Ji J, Liu A, Zhai G. Tumor targeting strategies for chitosan-based nanoparticles. Colloids and Surfaces B: Biointerfaces. 2016;148:460-73. doi: 10.1016/ j.colsurfb.2016.09.020, PMID 27665379.

86. Hema S, Thambiraj S, Shankaran DR. Nanoformulations for targeted drug delivery to prostate cancer: an overview. Journal of Nanoscience and Nanotechnology. 2018;18(8):5171-91. doi: 10.1166/jnn.2018.15420, PMID 29458568.

87. Hyun H, Park MH, Jo G, Kim SY, Chun HJ, Yang DH. Photo-cured glycol chitosan hydrogel for ovarian cancer drug delivery. Marine Drugs. 2019;17(1):1-12. doi: 10.3390/md17010041, PMID 30634553.

88. Babu A, Ramesh R. Multifaceted applications of chitosan in cancer drug delivery and therapy. Marine Drugs. 2017;15(4):119. doi: 10.3390/md15040096, PMID 28346381.

89. Danaei M, Dehghankhold M, Ataei S, Hasanzadeh Davarani F, Javanmard R, Dokhani A, Khorasani S, Mozafari MR. Impact of particle size and polydispersity index on the clinical applications of lipidic nanocarrier systems. Pharmaceutics. 2018;10(2):1-17. doi: 10.3390/pharmaceutics10020057, PMID 29783687.

90. Sorasitthiyanukarn FN, Muangnoi C, Ratnatilaka Na Bhuket PN, Rojsitthisak P, Rojsitthisak P. Chitosan/alginate nanoparticles as a promising approach for oral delivery of curcumin diglutaric acid for cancer treatment. Materials Science and Engineering C Mater Biol Appl. 2018;93:178-90. doi: 10.1016/j.msec.2018.07.069, PMID 30274050

91. Rosch JG, Winter H, Duross AN, Sahay G, Sun C. Inverse micelle synthesis of doxorubicin-loaded alginate/chitosan nanoparticles and in vitro assessment of breast cancer cytotoxicity. Colloids and Interface Science Communications. 2019;28:69-74. doi: 10.1016/j.colcom.2018.12.002, PMID 31602357 .

92. Shafawatbinti Rosli NS, Rahman AA, Aziz AA, Shamsuddin S, Ibrahim AR. The effect of gold nanoparticle size in the cellular uptake. Solid State Phenomena. 2019;290:75-80. doi: 10.4028/www.scientific.net/SSP.290.75.

93. Yang SJ, Shieh MJ, Lin FH, Lou PJ, Peng CL, Wei MF, Yao CJ, Lai PS, Young TH. Colorectal cancer cell detection by 5aminolaevulinic acid-loaded chitosan nano-particles. Cancer Letters. 2009;1273(2):210-20. doi: 10.1016/ j.canlet.2008.08.014, PMID 18809246.

94. Gederaas OA, Rasch MH, Berg K, Lagerberg JW, Dubbelman TM. Photodynamically induced effects in colon carcinoma cells (WiDr) by endogenous photosensitizers generated by incubation with 5-aminolaevulinic acid. Journal of Photochemistry and Photobiol B Iogy 1999;1344. 1999;49(23):162-70. doi: 10.1016/s1011-1344(99)00051-2, PMID 10392465.

95. Zhang Y, Zhang YN, Gao W, Zhou R, Liu F, Ng TB, Zhang Y, Zhang Y, Gao W, Zhou R, Liu F, Ng TB. A novel antitumor protein from the mushroom Pholiota nameko induces apoptosis of human breast adenocarcinoma MCF-7 cells in vivo and modulates cytokine secretion in mice bearing MCF-7 xenografts. International Journal of Biological Macromolecules. 2020;164:3171-8. doi: 10.1016/j.ijbiomac.2020.08.187, PMID 32858105.

96. Bazak R, Houri M, El Achy S, Kamel S, Refaat T. Cancer active targeting by nanoparticles: a comprehensive review of literature. Journal of Cancer Research and Clinical Oncology. 2015;141(5):769-84. doi: 10.1007/s00432-014-1767-3, PMID 25005786 .
97. Lungu II, Grumezescu AM, Volceanov A, Andronescu E. Nanobiomaterials used in cancer therapy: an up-to-date overview. Molecules. 2019;24(19):1-21. doi: 10.3390/molecules24193547, PMID 31574993.

98. Bilensoy E. Cationic nanoparticles for cancer therapy. Expert Opinion on Drug Delivery. 20202010;2010;7(7):795-809. doi: 10.1517/17425247.2010.485983, PMID 20446858.

99. Salatin S, Yari Khosroushahi AY. Overviews on the cellular uptake mechanism of polysaccharide colloidal nanoparticles Mechanisms of nanoparticle endocytosis. Journal of Cellular and Molecular Medicine. 2017;21(9):1668-86. doi: 10.1111/jcmm.13110, PMID 28244656.

100. Moraru C, Mincea M, Menghiu G, Ostafe V. Understanding the factors influencing chitosan-based nanoparticles-protein corona interaction and drug delivery applications. Molecules. 2020;25(20):1-33. doi: 10.3390/molecules25204758, PMID 33081296.

101. Ding L, Stilwell J, Zhang T, Elboudwarej O, Jiang H, Selegue JP, Cooke PA, Gray JW, Chen FF. Molecular characterization of the cytotoxic mechanism of multiwall carbon nanotubes and nanoonions on human skin fibroblast. Nano Lett. 2005;5(12):244864. doi: 10.1021/nl051748o, PMID 16351195.

102. Sutradhar KB, Amin ML. Nanotechnology in cancer drug delivery and selective targeting. ISRN Nanotechnol. 2014;2014:1-12. doi: 10.1155/2014/939378.

103. Borkowska M, Siek M, Kolygina DV, Sobolev YI, Lach S, Kumar S, Cho YK, Kandere-Grzybowska K, Grzybowski BA. Targeted crystallization of mixed-charge nanoparticles in lysosomes induces selective death of cancer cells. Nat Nanotechnol. 2020;15(4):331-41. doi: 10.1038/s41565-020-0643-3. PMID 32203435 .

104. Chivere VT, Kondiah PPD, Choonara YE, Pillay V. Nanotechnology-based biopolymeric oral delivery platforms for advanced cancer treatment. Cancers. 2020;12(2):1-22. doi: 10.3390/cancers12020522, PMID 32102429.

105. Pedraza JC, Cardenas NR, Orozco MI, Perez JM, PedrazaChaverri J, Cardenas Rodriguez N, Orozco Ibarra M, Perez Rojas JM. Medicinal properties of mangosteen (Garcinia mangostana). Food and Chemical Toxicology. 2008;46(10):3227-39. doi: 10.1016/j.fct.2008.07.024, PMID 18725264.

106. Jacob S, Nair AB, Shah J. Emerging role of nanosuspensions in drug delivery systems. Biomater Res. 2020;24:3. doi: 10.1186/s40824-020-0184-8. PMID 31969986.

107. Wu L, Zhang J, Watanabe W. Physical and chemical stability of drug nanoparticles. Advanced Drug Delivery Reviews. 2011;63(6):456-69. doi: 10.1016/j.addr.2011.02.001, PMID 21315781.

108. Yadollahi R, Vasilev K, Simovic S. Nanosuspension technologies for delivery of poorly soluble drugs. Journal of Nanomaterials. 2015;2015:1-13. doi: 10.1155/2015/216375.

109. Chenthamara D, Subramaniam S, Ramakrishnan SG, Krishnaswamy S, Essa MM, Lin FH, Qoronfleh MW. Therapeutic efficacy of nanoparticles and routes of administration. Biomater Res. 2019;23:20. doi: 10.1186/s40824-019-0166-x. PMID 31832232.

110. Farasat A, Rahbarizadeh F, Ahmadvand D, Ranjbar S, Khoshtinat Nikkhoi SK. Effective suppression of tumour cells by oligoclonal HER2-targeted delivery of liposomal doxorubicin. Journal of Liposome Research. 2019;29(1):53-65. doi: 10.1080/08982104.2018.1430829, PMID 29621912.

111. Bilensoy E. Cationic nanoparticles for cancer therapy. Expert Opinion on Drug Delivery. 2010;7(7):795-809. doi: 10.1517/17425247.2010.485983.

112. Dermawan D, Wathoni N, Muchtaridi M. Host-guest interactions of $\alpha$-mangostin with $(\alpha, \beta, \gamma)$ - cyclodextrins: semiempirical quantum mechanical methods of PM6 and PM7. Journal of Young Pharmacists. 2018;11(1):31-5. doi: 10.5530/jyp.2019.11.7. 